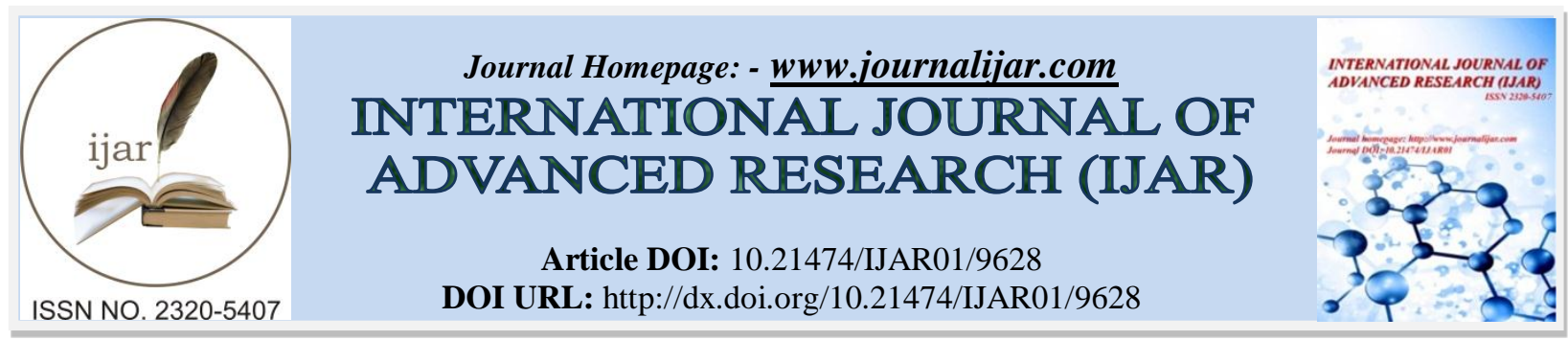

RESEARCH ARTICLE

\title{
DESIGN AND DEVELOPMENT OF TALKING BRAILLE CALCULATOR.
}

Cheerobie Aranas, Ramon Flores-, Rina Arcigal and Jonnel Pabico.

College of Engineering, Laguna State Polytechnic University Philippines.

\section{Manuscript Info}

Manuscript History

Received: 02 July 2019

Final Accepted: 04 August 2019

Published: September 2019

\begin{abstract}
This research focused on the design and development of a Talking Braille Calculator. More specifically, the following were the objectives of the study: specify the technology requirements needed for the development of a Talking Braille Calculator; test the Talking Braille Calculator in terms of its responsiveness, synchronization and accuracy and evaluate the Talking Braille Calculator in terms of effectiveness.

The Talking Braille Calculator was developed to help the visuallyimpaired students to study and SPED teachers to teach the four Mathematical operations with the implementation of Braille Writing system. It was set to provide an advanced tool for the visually-impaired students and teachers of Santa Cruz Central Elementary School (SCES), Sta. Cruz, Laguna.

The design of the Talking Braille Calculator used the idea of the conventional calculators with the implementation of Nemeth codes programmed in order to mount the answer through the braille pins attached to the device using a servo motor. The keys, buttons and braille pins can talk when pressed using the pre-recorded voice installed into the voice module.

The research resulted to use C Programming Language to program the PIC microcontroller that controls the whole device including the voice module and the servo motor. It can process a whole operation in 13.05 sec. which consist of four digits, and one operator pressed with the result matching the pre-recorded voice and the display.

The device obtained 4.903 weighted mean average interpreted as Highly Acceptable evaluated by the visually- impaired students.
\end{abstract}

Copy Right, IJAR, 2019,. All rights reserved.

\section{Introduction:-}

"Education is the most powerful weapon which you can use to change the world" (Nelson Mandela) ${ }^{1}$. No matter what condition a person is in, education is essential to self- development and self- worth. Education for visually impaired persons is impossible until the introduction of Braille Writing System- a system for reading with the fingertips that is used as a guide in learning the basic and advance subjects offered in a normal school.

Ordinary students, even if they have all the resources and good mathematical skills face difficulty in analysing and computing mathematical problems, what more if the students are visually impaired or blind.

A normal person can use a calculator easily and trouble-free but to those who are blind or visually impaired; operating a calculator will be difficult because they cannot see it. This is the main initiative of the study made by 
Bituin $^{2}$ et. al. (2013) titled "Design of a Braille Calculator: An Innovative Tool for a Blind Person" that created a new tool for the blind that uses the function of a normal calculator with the Braille Writing System. The Braille Calculator is only limited to one-digit input and two-digit output, the answers will be then touched using the solenoid pins attached to the device.

These serves as the inspiration of the researchers to design and develop the above-mentioned study to improve its effectiveness making it talk. Talking Braille Calculators can be an alternative tool in solving basic mathematical operations for visually impaired or blind persons. This may help them learn Mathematics and improve their familiarity with Braille Writing System. With proper training, skill and knowledge, visually impaired persons can have the equal opportunity with normal people hence, physical disability is not a hindrance anymore to attain their goals in life.

\section{Developmental Methods:-}

The purpose of developmental research is to assess changes over an extended period of time. Problem definition procedures encompass focusing on and framing the problem, and identifying the limitations of the research. The problem is created through the development of the Braille Calculator by Bituin ${ }^{2}$ et.al (2013) and is the main stimulus of this project, the "Talking Braille Calculator".

Developmental research has been defined as the systematic study of designing, developing, and evaluating instructional programs, processes, and products that must meet criteria of internal consistency and effectiveness. Developmental research is particularly important in the field of instructional technology.

This type of research method uses many types of resources like special purpose books, internet access, including related studies or thesis and other forms of writing that will help the researches to gather relevant information. From the gathered information, the researchers experienced a systematic process in making the project possible. This includes interviewing and designing in order to achieve and to meet the demand for evaluation.

This project will use the most common type of Developmental research, which involves situations in which the product-development process is analyzed and described, and the final product is evaluated. The Talking Braille Calculator will also focus more on the impact of the product on the learner of the SPED unit of Santa Cruz Central Elementary School.

The study uses purposive sampling wherein the respondents are selected based on their expertise. The chosen respondents of the study were the teachers and visually- impaired student from the SPED Unit of Santa Cruz Central Elementary School, Santa Cruz, Laguna.

The researchers prepared fifteen (15) questions answered by six (15) people from the educational institution including the five (5) teachers, seven (7) SPED major students, and one (1) visually- impaired student against their current technology in teaching and learning Mathematics. The respondents answered the effectiveness of the design project as provided by the researchers.

Evaluation form was provided by the respondents upon doing several assessments concerning the level of the acceptability of the prototype in order to gather the needed data. The evaluation form includes fifteen (15) questions to prove the level of acceptability of the device in terms of effectiveness. The respondents have to rate the "Talking Braille" from 1 to 5, where 5 is rated as Highly Acceptable, 4 is Acceptable, 3 is for Fair, 2 is for Undecided and 1 is for Unacceptable.

The questionnaires were studied and validated upon consultation of the researchers to their respective statistician and project adviser.

\section{Results And Discussion:-}

The development of the Talking Braille Calculator was conceptualized based on the previous study titled Design of a Braille Calculator: An Innovative Tool for a Blind Person ${ }^{2}$ (2013). The previous study can only hold one digital input and two digital output, while for this study, the prototype Braille Calculator is set to managed 2 digits input and up to 4 digits output. Moreover, the numerical answer of the calculator will not only be flashed on the display to 
convey through audible voice pre-recorded and pre- programmed within the prototype. Earphone jack is also included as additional feature for ease of access.

It has sixteen (16) embossed braille keypad and braille solenoid pin that display its output. The solenoid pins are designed to emerge the answers in the form of the braille system. There is also an extra button, it is for the answer display, whenever the answer is more than one digit the users can press it and the next number will be conversed and appear in the solenoid pins and it is also for the answer repetition, when the user wants to repeat the final answer they can press again the button. The prototype had a microcontroller board using C Programming for the software part and a voice module so that the user can change the recorded voice with what they want.

For every braille keypad that can be pressed the calculator to voice out the corresponding number. The prototype is powered by batteries to become more portable to the users, but an AC adapter can also be plugged in.

The calculator can perform the four basic operations of mathematics, addition, subtraction, multiplication, and division. Aside from the basic four operations, it also recognized negative numbers and as for division operation the final answer is round off to whole numbers for it cannot recognize decimal numbers. And if the user pressed the wrong key there is a clear button to restart the device.

Table 1:-Performance testing on the Responsiveness of the Keypad in parallel to the pre-recorded voice and LCD

\begin{tabular}{|l|l|l|}
\hline Input & Time & Remarks \\
\hline One Digit & $1.21 \mathrm{sec}$. & Responsive \\
\hline Two Digit & $2.41 \mathrm{sec}$. & Responsive \\
\hline Whole Operation & $10.29 \mathrm{sec}$. & Responsive \\
\hline Whole Operation with Answer & $15.06 \mathrm{sec}$. & Responsive \\
\hline
\end{tabular}

The whole operation with answer consumes 15.06 seconds, four digits and one operator were pressed and the fourdigit answer was displayed to the braille pins that matched the pre-recorded voice.

Table 2:-Performance testing on the synchronization of the keypad to the pre-recorded voice

\begin{tabular}{|l|l|l|}
\hline Input & Output (Pre- recorded Voice) & Remarks \\
\hline 1 & One & Synchronized \\
\hline 2 & Two & Synchronized \\
\hline $\mathrm{X}$ & Times & Synchronized \\
\hline 5 & Five & Synchronized \\
\hline+ & Plus & Synchronized \\
\hline$\div$ & Divide & Synchronized \\
\hline
\end{tabular}

The synchronization of the keypad to the pre-recorded voice is also verified through series of test as shown on Table No.6. Input shows the digits or keys that are pressed while the output is the pre-recorded voice. All the tests are marked as synchronized.

Table 3:-Performance testing on the accuracy of the Result

\begin{tabular}{|c|c|c|c|c|}
\hline Input & $\begin{array}{c}\text { Nemeth } \\
\text { Code }\end{array}$ & Output & $\begin{array}{c}\text { Nemeth } \\
\text { Code }\end{array}$ & Remarks \\
\hline $1+1$ & + & 2 & $=$ & Accurate \\
\hline $56-30$ & $\because: \cdots+\cdots$ & 20 & $=\quad \therefore$ & Accurate \\
\hline $10 \times 20$ & $\because \quad \therefore x=\quad \therefore$ & 200 & $=\quad \therefore$ & Accurate \\
\hline $10 / 2$ & $\because \div \div=$ & 5 & $\because$ & Accurate \\
\hline $50-70$ & $\because:_{-}: 2:$ & -20 & $\ldots=\ldots$ & Accuratel \\
\hline
\end{tabular}


The researchers conducted a test on the accuracy of the output of the Talking Braille Calculator with the help of the visually- impaired student from SCES. The test was composed of all the four Mathematical operations present in the Talking braille calculator. Addition, Multiplication, Division and Subtraction with negative difference were all tested and all were verified generating accurate outputs.

Table 4:-Level of Acceptability of the "Talking Braille Calculator" in terms of Effectiveness

\begin{tabular}{|l|l|l|l|l|}
\hline Criteria & $\begin{array}{l}\text { Weighted } \\
\text { Mean }\end{array}$ & $\begin{array}{l}\text { Standard } \\
\text { Deviation }\end{array}$ & Description & Verbal Interpretation \\
\hline $\begin{array}{l}\text { 1. The keys correspond to the } \\
\text { right Nemeth code. }\end{array}$ & 5.000 & 0 & Strongly Agree & Highly Acceptable \\
\hline $\begin{array}{l}\text { 2. The braille pins are well } \\
\text { distinguished. }\end{array}$ & 4.616 & 0.474 & Strongly Agree & Highly Acceptable \\
\hline $\begin{array}{l}\text { 3. The pre- recorded voice is } \\
\text { synchronized to the keys when } \\
\text { pressed one at a time. }\end{array}$ & 5.000 & 0 & Strongly Agree & Highly Acceptable \\
\hline $\begin{array}{l}\text { 4. The device is convenient to } \\
\text { use. }\end{array}$ & 4.616 & 0.474 & Strongly Agree & Highly Acceptable \\
\hline $\begin{array}{l}\text { 5. The device can perform the } \\
\text { four basic operations. }\end{array}$ & 4.616 & 0.474 & Strongly Agree & Highly Acceptable \\
\hline $\begin{array}{l}\text { 6. The pre- recorded voice is } \\
\text { well modulated } \\
\text { understandable. }\end{array}$ & 5.000 & 0 & Strongly Agree & Highly Acceptable \\
\hline $\begin{array}{l}\text { 7. The device can calculate up to } \\
\text { two digits. }\end{array}$ & 5.000 & 0 & Strongly Agree & Highly Acceptable \\
\hline $\begin{array}{l}\text { 8. The pre- recorded voice } \\
\text { matches the braille pins. }\end{array}$ & 5.000 & 0 & Strongly Agree & Highly Acceptable \\
\hline $\begin{array}{l}\text { 9. The braille pins changes } \\
\text { quickly when needed. }\end{array}$ & 4.923 & 0.277 & Strongly Agree & Highly Acceptable \\
\hline $\begin{array}{l}\text { 10. The braille pins correspond } \\
\text { to the right Nemeth code. }\end{array}$ & 4.923 & 0.277 & Strongly Agree & Highly Acceptable \\
\hline $\begin{array}{l}\text { 11. The earphones are working } \\
\text { properly. }\end{array}$ & 5.000 & 0 & Strongly Agree & Highly Acceptable \\
\hline 12. The keys are responsive. & 4.923 & 0.277 & Strongly Agree & Highly Acceptable \\
\hline $\begin{array}{l}\text { 13. The keys are well- } \\
\text { distinguished. }\end{array}$ & 4.923 & 0.277 & Strongly Agree & Highly Acceptable \\
\hline $\begin{array}{l}\text { 14. The results are accurate. } \\
\text { 15. The device can repeat the } \\
\text { result. }\end{array}$ & 5.000 & 0 & Strongly Agree & Highly Acceptable \\
\hline Average Weighted Mean & $\mathbf{4 . 9 0 3}$ & 0 & Highly Acceptable \\
\hline
\end{tabular}

The Talking Braille Calculator has 4.903 weighted mean which proves that the device is Highly Acceptable in terms of its effectiveness.

\section{Conclusion:-}

Based on the previous findings and result of the project study on the Talking Braille Calculator, the researchers hereby formulated that the objectives were met with the following conclusions:

1. The researchers were able to use the 28/40-Pin 8-Bit PIC16F87X CMOS Flash Microcontroller and C programming language to meet the technology requirement for designing and developing the Talking Braille Calculator.

2. The $\mathrm{C}$ programming language suited the MPLAB IDE in order to program PIC microcontroller.

3. The 28/40-Pin 8-Bit PIC16F87X CMOS Flash Microcontroller can store all the needed data and connect all the needed module to run the Talking Braille calculator.

4. The researchers were able to design and develop the Talking Braille calculator with the following features:

5. It can process a whole operation in 13.05 seconds only with four digits pressed and one operator but still depends on the visually- impaired student's knowledge on braille writing system. 
6. The keypad and buttons are synchronize to the pre-recorded voice when pressed.

7. The device is accurate but will not consider the significant figures of the result.

8. The researchers have tested and evaluated the level of acceptability of the Talking Braille Calculator to the in terms of effectiveness with general weighted mean of 4.903 that concluded that the device is Highly acceptable.

\section{References:-}

1. Mandela, (2013) Education: The Most Powerful Weapon for Changing the World

2. Bituin, et. Al. (2013) Development of Braille Calculator

3. Ackermann, Ernest C. (2015). C Programming Language Essentials, Essential Study Guides. Research \&Education Association, 2015. Page 2-3. 2 Retrieve from https://books.google.com.ph/books?id=fj0m3Y6zXCUCpg=PA1\&dq=c+programming+language \&hl=en\&sa $=X$ \&ved=0ahUKEwjtlejC3cPaAhXFpY8KHZi_A9U4ChDoAg1MAQ\#v=onepage\&q=c\%20programming\%20lan guage $\& \mathrm{f}=$ false

4. AudioMan (2016). Earphones, Earbuds, Canalphones: What's the Difference? Article retrieved on October 9,2017 from https://www.audiolinks.com/blog/earphones-earbuds-canalphones/

5. Baig, Edward C. and LeVitus, Bob (2011) IPad 2 For Dummies. John Wiley \& Sons. Page 280. Retrieved on

6. October 7, from https://books.google.com.ph/books?id=slNS72LxHVwC\&pg=PA280\&dq=earphones\&hl=en\&sa=X\&ved=0ah UKwig15z1zOLWAhVEXbwKHZHNBugQ6AEIQTAF\#v=onepage\&q\&f=false

7. Ballou, Glen (2015). Handbook for Sound Engineers., The Hazard of Earbuds. CRC Press, 5 Mar 2015. $\begin{array}{lllll}\text { Retrieved on } & \text { October } & 9, & 2017 & \text { from }\end{array}$ https://books.google.com.ph/books?id=8BLwBgAAQBAJ\&pg=PT217\&dq=earphone+and+earbuds\&hl=en\&sa $=X \& v e d=0 a h U K E w j 4 \mathrm{mZvgkOPWAhWL2LwKHa9vBkk4ChDoAQhOMAY \# v=onepage \& q=earphone \% 20and}$ $\% 20$ earbuds $\& \mathrm{f}=$ false

8. Becker, Cher (2009). Soft Shell In-ear Earphones with Miniature Speaker Inserts. Page 1. Retrieved from https://docs.google.com/viewer?url= patentimages.storage.googleapis.com/pdfs/US20100195860.pdf

9. Chaudhary, Harry H. (2014). The C Programming Language. Createspace LLC USA, 2014. Page no. 16. Retrieve

from https://books.google.com.ph/books?id=6qgBBAAAQBAJ\&printsec=frontcover\&dq=c+programming+language $\& \mathrm{hl}=\mathrm{en} \& \mathrm{sa}=\mathrm{X} \& \mathrm{ved}=0 \mathrm{ahUKEwiY2eadosTaAhXGMI} 8 \mathrm{KHUP} 4 \mathrm{~A} 3 \mathrm{gQ6}$ AEIKzAB\#v=onepage $\& \mathrm{q}=\mathrm{c} \% 20$ program ming\%20language $\& \mathrm{f}=$ false

10. Chen Chunpinga et al. (2011). Research and Development of C Language Programming Experiment Assistant Management Platform Based on Hybrid Architecture. College of Information, Qingdao University of Science \& Technology, Qingdao, China. Elsevier Ltd, 2011. Retrieved from https://ac.elscdn.com/S1877705811020534/1-s2.0-S1877705811020534-main.pdf?_tid=235c60b4-87bd-4daf-a20c84f50276b41f\&acdnat=1524069136_6fbca7a7c2e5d8bdba9de66d276e1adc

11. Clifton, Jacob (2017). How A Calculator Works? Article retrieve on October 11, 2017 from http://electronics.howstuffworks.com/gadgets/othergadgets/calculator3.html 